\title{
REPROCESSING OF NUCLEAR FUELS BY VOLATILITY SEPARATIONS IN FLUIDIZED BEDS
}

S.J. Wachtel, J.J. Reilly, C.B. Bartlett, R. Johnson, and E. Wirsing, Jr.

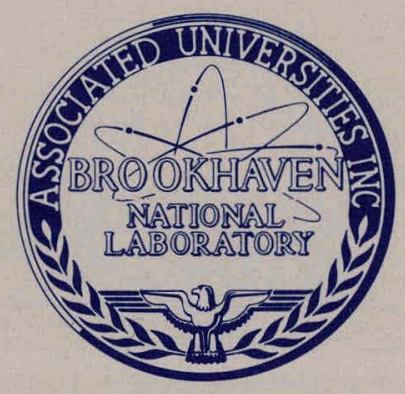

March 1966

BROOKHAVEN NATIONAL LABORATORY

Associated Universities, Inc.

under contract with the

UNITED STATES ATOMIC ENERGY COMMISSION 


\section{DISCLAIMER}

This report was prepared as an account of work sponsored by an agency of the United States Government. Neither the United States Government nor any agency Thereof, nor any of their employees, makes any warranty, express or implied, or assumes any legal liability or responsibility for the accuracy, completeness, or usefulness of any information, apparatus, product, or process disclosed, or represents that its use would not infringe privately owned rights. Reference herein to any specific commercial product, process, or service by trade name, trademark, manufacturer, or otherwise does not necessarily constitute or imply its endorsement, recommendation, or favoring by the United States Government or any agency thereof. The views and opinions of authors expressed herein do not necessarily state or reflect those of the United States Government or any agency thereof. 


\section{DISCLAIMER}

Portions of this document may be illegible in electronic image products. Images are produced from the best available original document. 


\section{LEG A L NOTICE}

This report was prepared as an account of Government sponsored work. Neither the United States, nu the Cunnnissivn, nü any pus sun ac ling un belialf of the Cunnnissivin.

A. Makes any warranty or representation, expressed or implied, with respect to the accuracy, completeness, or usefulness of the information contained in this report, or that the use of any information, apparatus, method, or process disclosed in this report may not intringe privately owned rights; or

B. Assumes any liabilities with respect to the use of, or for damages resulting from the use of any information, apparatus, method, or proccss disclosed in this report.

As used in the above, "person acting on behalf of the Commission" includes any employee or contractor of the Commission, or employee of such contractor, to the extent that such employee or contractor of the Commission, or employee of such contractor prepares, disseminates, or provides access to, any information pursuant to his employment or contract with the Commission, or his employment with such contractor.

\section{PRINTED IN USA}

PRICE $\$ 1.00$

Available from the

Clearinghouse for Federal Scientific and Technical Information

National Bureau of Standards

U.S. Department of Commerce

Springfield, Virginia 
BNL 973 ( $T$ - 409)

(Chemical Separations Processes for

Plutonium and Uranium - TID-4500)

CESTI PRICES

H.C. $1.00, \operatorname{MN} .50$ REPROCESSING OF NUCLEAR FUELS BY VOLATILITY SEPARATIONS IN FLUIDIZED BEDS

S.J. Wachtel, J.J. Reilly, C.B. Bartlett, R. Johnson, and E. Wirsing, Jr.

March 1966

BROOKHAVEN NATIONAL LABORATORY UPTON, NEW YORK 11973 


\section{REPROCESSING OF NUCLEAR FUELS BY VOLATILITY SEPARATIONS IN FLUIDIZED BEDS}

\section{Introduction}

The use of fluidized beds of inert granular material as an effective means of temperature control in the volatility reprocessing of nuclear reactor fuels has received increasing attention in recent years. ${ }^{1}$ The unique advantage of the fluidized bed is that it is an efficient, noncorrosive, heat transfer medium for carrying out highly exothermic gas-solid reactions. Since 1958 a continuing experimental study has been cunducted at Brookhaven National I.aboratory (BNL) in which the basic steps of the fluidized bed volatility process have been developed for a number of unirradiated fuel types. Generally, two major operations are required:

1) A head-end reaction at elevated temperatures in which the fuel cladding or matrix material is disintegrated or volatilized.

2) A reaction with fluorine at temperatures as high as $550^{\circ} \mathrm{C}$ in which the fissile material is recovered as volatile hexafluoride.

This report summarizes the results of the BNL fluidized bed volatility studies.

\section{Uranium and Zirconium-Uranium Alloy Fuels}

In these fluidizedbed studies the first highly exothermic reaction carried out was that between fluorine and metallic uranium coupons. ${ }^{2}$ These early experiments showed that relatively massive pieces of uranium could be rapidly reacted with fluorine gas to form volatile $\mathrm{UF}_{6}$ with close temperature control, whereas without the fluidized bed such a reaction would produce large temperature excursions.

Further studies, also reported by Reilly et al. ${ }^{2}$ demonstrated that uranium could be recovered from Zircaloy clad $\mathrm{Zr}$-U alloy fuel using a declad-fluorination sequence. The primary reactions are as follows:

$$
\begin{array}{r}
\mathrm{Zr}(s)+4 \mathrm{HCl}(g) \stackrel{450^{\circ} \mathrm{C}}{\rightarrow} \mathrm{ZrCl}_{4}(g)+2 \mathrm{H}_{2}(g) \\
2 \mathrm{U}(s)+6 \mathrm{HCl}(g) \stackrel{450^{\circ} \mathrm{C}}{\rightarrow} 2 \mathrm{UCl}_{3}(s)+3 \mathrm{H}_{2}(g) \\
2 \mathrm{UCl}_{3}(s)+6 \mathrm{~F}_{2}(g) \stackrel{450^{\circ} \mathrm{C}}{\rightarrow} 2 \mathrm{UF}_{6}(g)+3 \mathrm{CL}_{2}(g)
\end{array}
$$

The fuel was immersed in a fluidized bed of alumina and reacted with gaseous $\mathrm{HCl}$ to convert the zirconium constituent of the cladding and alloy to volatile $\mathrm{ZrCl}_{4}$. The uranium, at the same time, was converted to nonvolatile $\mathrm{UCl}_{3}$ which was then reacted with fluorine and recovered as $\mathrm{UF}_{\varepsilon}$. In other experiments it was demonstrated that $\mathrm{ZrCl}_{4}$ could be converted to $\mathrm{ZrO}_{2}$ with steam in a separate fluidized-bed reactor. Hydrochlorination experiments, carried out in a 6-in.-diameter fluidized-bed reactor with PWR-type multiplate fuel assemblies, proved that the alumina bed material could be fluidized between the plates ( $<0.1 \mathrm{in}$. spacing) of these assemblies to remove the heat of the decladding reaction, thereby preventing melt-down of the fuel. Results of these runs and of the uranium fluorination studies were reported by Regan et al. ${ }^{3}$ Based on these findings an extensive program was initiated at Argonne National Laboratory to carry out the process development through the integrated pilot plant stage. ${ }^{4,5}$

\section{Graphite Matrix Fuels}

As in the case of $\mathrm{Zr}-\mathrm{U}$ alloy fuels, graphite matrix fuels lend themselves readily to the fluidized-bed volatility method of reprocessing. While a number of other methods have been considered for reprocessing graphite matrix fuels (such as grinding the fuel followed by acid leaching of the uranium, ${ }^{6}$ or high pressure aqueous chemical combustion ${ }^{7}$ ), burning of the graphite material with oxygen remains the most straightforward and efficient method of exposing the contained uranium for subsequent recovery by fluorination or acid leaching.

In direct burning experiments, without the addition of any inert bed material, ${ }^{8}$ it was found that the high heat fluxes generated, coupled with poor thermal conductivity, resulted in high fuel centerline temperatures, sintering of the product, and excessive local temperatures at the vessel walls.

In contrast, rapid combustion of the fuel in a fluidized bed of alumina with pure oxygen used as the fluidizing gas was carried out with good 
temperature control at approximately $750^{\circ} \mathrm{C} .{ }^{9}$ For example, a $\Delta T$, centerline of the bed to the reactor wall, of only $30^{\circ} \mathrm{C}$ was experienced in a 4-in.-diameter vessel in which graphite matrix fuel was being burned at a rate of $15 \mathrm{~kg} / \mathrm{hr}-\mathrm{ft}^{2}$ reactor cross section. The heat transfer coefficient, bed to wall, was calculated to be $\approx 70 \mathrm{Btu} / \mathrm{hr}-\mathrm{ft}^{2}-{ }^{\circ} \mathrm{F}$.

Bench-scale experiments were carried out to determine uranium recovery from unirradiated graphite matrix fuels using the fluidized-bed oxidation-fluorination steps. On the basis of the favorable results obtained in these tests,$^{10}$ a pilot plant was constructed to carry out uranium recovery experiments with unirradiated graphite matrix fuels on a more comprehensive scale.' Fig. 1 shows the pilot plant flow sheet for the reprocessing studies on the graphite matrix fuel typical of that being tested in the Rover nuclear rocket program. ${ }^{11}$ The Rover fuel used contains pyrographite-coated uranium dicarbide particles dispersed in a graphite matrix. Propellant passages through the fuel element are lined with niobium carbide to protect the graphite against the corrosiveness of high temperature hydrogen.

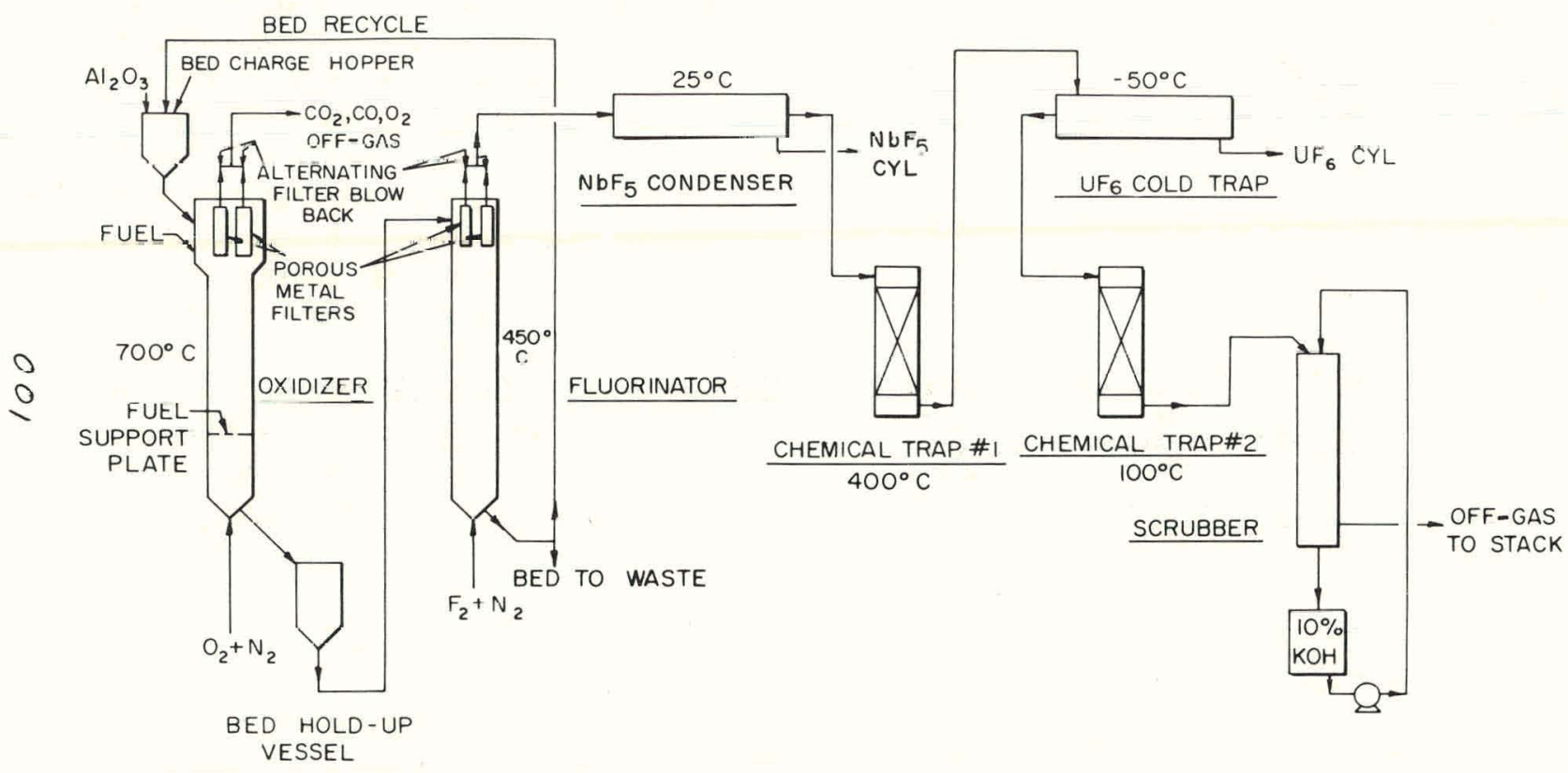

Figure 1. Continuous oxidation-batch fluorination pilot plant flow sheet.

The major reactions taking place in the oxidation step are:

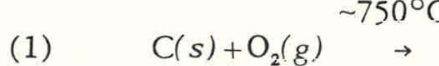
$\mathrm{CO}_{2}(\mathrm{~g})$
$\Delta H_{298}^{\circ}=-94 \mathrm{kcal}$
$\mathrm{C}(\mathrm{s})+1 / 2 \mathrm{O}_{2}(\mathrm{~g}) \rightarrow$
$\mathrm{CO}(\mathrm{g})$
$\Delta H_{298}^{\circ}=-26 \mathrm{kcal}$
(3) $3 \mathrm{UC}_{2}(\mathrm{~s})+10 \mathrm{O}_{2}(\mathrm{~g}) \rightarrow$
$\mathrm{U}_{3} \mathrm{O}_{8}(s)+6 \mathrm{CO}_{2}(g) \Delta H^{\circ}{ }_{298}=-1333 \mathrm{kcal}$
(4) $2 \mathrm{NbC}(s)+4 \frac{1}{2} \mathrm{O}_{2}(g) \rightarrow$
$\mathrm{Nb}_{2} \mathrm{O}_{5}(s)+2 \mathrm{CO}_{2}(g) \Delta H_{298}^{\circ}=-579 \mathrm{kcal}$

Uranium was recovered from the bed in a fluoride volatility step in which the following major reactions occur:
(5)
$\mathrm{U}_{3} \mathrm{O}_{8}(s)+9 \mathrm{~F}_{2}(g)$
$\rightarrow 3 \mathrm{UF}_{6}(g)+4 \mathrm{O}_{2}(g)$
$\Delta H^{\circ}{ }_{298}=-696 \mathrm{kcal}$
(6) $\mathrm{Nb}_{2} \mathrm{O}_{5}(s)+5 \mathrm{~F}_{2}(g) \rightarrow 2 \mathrm{NbF}_{5}(g)+2 \frac{1}{2} \mathrm{O}_{2}(g)$
$\Delta H_{298}^{\circ}=-229 \mathrm{kcal}$ 
The oxidation was carried out in a continuous manner in a 4-in.-diameter, 12-ft.-long reactor vessel. The granular alumina bed was fluidized to a 6-ft length with oxygen which was fed through a ball check in the conical bottom of the reactor. Chopped fuel was added intermittently to the fluidized bed as required to maintain a high burning rate. Combustion gases, mainly $\mathrm{CO}_{2}$, with small quantities of $\mathrm{CO}, \mathrm{N}_{2}$ and $\mathrm{O}_{2}$, were passed through porous metal filters and then to the stack. Plugging of filters was prevented by means of a pulsed blowback with nitrogen. The reactor was air cooled to remove the heat of reaction, and the temperature was maintained between $700^{\circ}$ and $750^{\circ} \mathrm{C}$. During the course of the reaction, bed material, rich in $\mathrm{U}_{3} \mathrm{O}_{8}$ and $\mathrm{Nb}_{2} \mathrm{O}_{5}$ oxidation products and essentially free of carbon, was withdrawn periodically from the bottom of the reactor while recycled bed material from the fluorinator, or makeup alumina, was added at the top.

Bed material discharged from the oxidizer was pneumatically conveyed to a 4-in.-diameter vessel where it was reacted with fluorine gas at $450^{\circ} \mathrm{C}$ in a batch operation. The off-gases from the fluorinator, which contained $\mathrm{UF}_{6}, \mathrm{NbF}_{5}, \mathrm{~F}_{2}, \mathrm{~N}_{2}$, and $\mathrm{O}_{2}$, were passed through porous metal filters and conducted to the uranium recovery system which consisted of four units. These were: 1) an $\mathrm{NbF}_{5}$ condenser, 2) a high temperature $\mathrm{NaF}$ column which served as an $\mathrm{NbF}_{5}$ cleanup trap, 3) a $\mathrm{UF}_{6}$ desublimer, and 4) a low temperature $\mathrm{NaF}$ column for final $U_{6}$ recovery. The off-gases were finally passed through a spray tower where they were contacted with a $10 \% \mathrm{KOH}$ solution to remove unreacted fluorine from the stream.

Results of the continuous oxidation of the Rover fuel are shown in Fig. 2. High burning rates, averaging 1.2 to $1.3 \mathrm{~kg}$ of carbon $/ \mathrm{hr}$ [14 to $15(\mathrm{~kg} \mathrm{C}) / \mathrm{hr}^{-} \mathrm{ft}^{2}$ reactor cross section], were maintained during periods of extended operation. Oxygen utilization consistently was greater than $95 \%$ and the off-gas contained, generally, 80 to $90 \mathrm{vol}$ $\% \mathrm{CO}_{2}$ and 5 to 10 vol $\% \mathrm{CO}$.

Five fluidized-bed fluorination experiments were carried out. The bed material contained up to 30 wt \% combined $\mathrm{U}_{3} \mathrm{O}_{8}$ and $\mathrm{Nb}_{2} \mathrm{O}_{5}$ and, with one exception, $<0.3$ wt $\%$ carbon. Over-all uranium recovery for the five experiments was $99.2 \%$. Temperatures during fluorination ranged from $450^{\circ}$ to $510^{\circ} \mathrm{C}$. Separation of $\mathrm{UF}_{6}$ from the $\mathrm{NbF}_{5}$ was satisfactory.

The pilot plant was also operated with the graphite matrix fuel used in the high temperature gas-cooled reactor (HTGR). ${ }^{9}$ This fuel is composed of pyrocarbon-coated uranium-thorium dicarbide particles dispersed in a graphite matrix. Oxidation of this fuel proceeded smoothly as with the Rover fuel but at a somewhat lower rate. The fluorination step, however, was more complex. With Rover fuel all of the uranium becomes exposed as the carbon is removed and can be volatilized as $\mathrm{UF}_{6}$. However, with HTGR fuel, a significant portion of the uranium is trapped as $\mathrm{U}_{3} \mathrm{O}_{8}$ within the solid thorium fluoride $\left(\mathrm{ThF}_{4}\right)$ formed by fluorination of the $\mathrm{ThO}_{2}$ oxidation product. In order to recover this uranium by fluorination, the $\mathrm{ThF}_{4}$ solid must be broken up. The action of high temperature steam, which serves to reconvert the $\mathrm{ThF}_{4}$ to $\mathrm{ThO}_{2}$, has been found effective in this regard.

A series of bench-scale experiments ${ }^{9}$ was carried out in which HTGR fuel was first oxidized in a fluidized bed of alumina and was then fluorinated. Fig. 3 shows the results of the fluorination experiments. The bed initially contained 20,000 ppm of uranium and 80,000 ppm of thorium. In a 150 -minute fluorination the uranium concentration was reduced to approximately $1000 \mathrm{ppm}$. An additional 130 minutes of fluorination with $100 \% \mathrm{~F}_{2}$ at $550^{\circ} \mathrm{C}$ resulted in essentially no further reduction in uranium concentration. At this point the bed was reacted with a mixture of $80 \%$

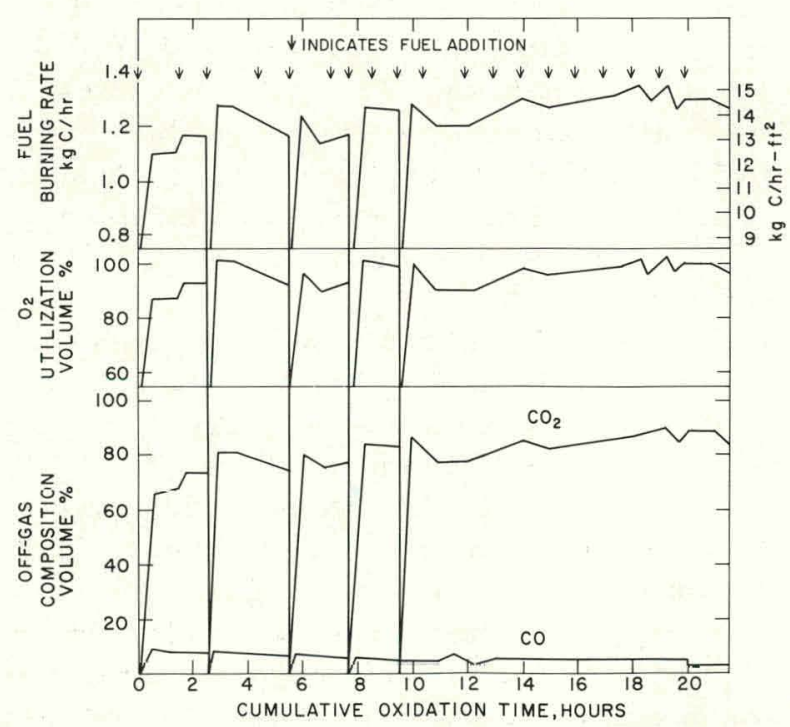

Figure 2. Continuous fluid-bed oxidation of Rover fuel. 


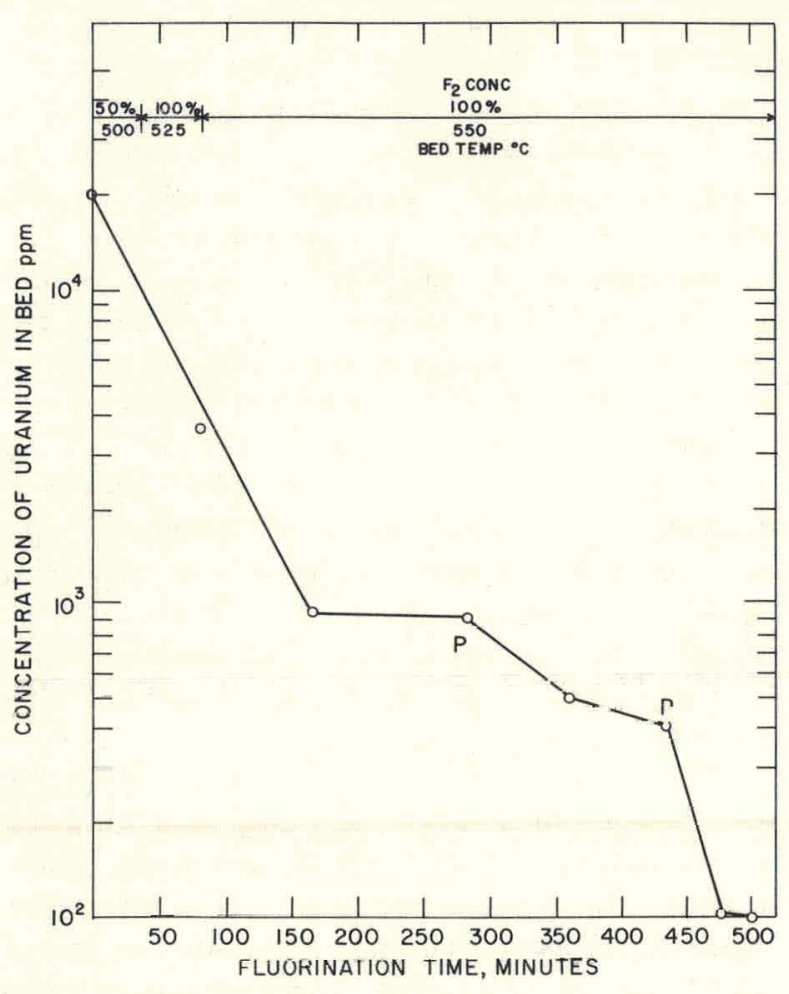

Figure 3. Recovery of uranium from high temperature gas-cooled reactor fuel oxidation products. The points labeled $\mathrm{P}$ indicate interruption for pyrohydrolysis step.

steam-20\% nitrogen at a temperature of $500^{\circ} \mathrm{C}$ for 2 hours. After this pyrohydrolysis step, fluorination was resumed. The cycle was repeated once more and, after a total of 500 minutes of fluorination, the residual concentration of uranium in the bed was found to be approximately $100 \mathrm{ppm}$. This is equivalent to $99.5 \%$ uranium volatilizatinn from the bed.

An alternative method for reprocessing graphite matrix fuels, i.e., by means of burning in a fluidized bed and leaching the oxidation product with acid, was studied with both Rover and HTGR tuel. The head-end fluidized-bed oxidation step was identical with that used in the burnfluorination studies reported above. With Rover fuel, bench-scale and pilot plant scale leaching experiments, carried out after fluidized-bed oxidation, indicated that an oxidation-leach process for recovering the uranium is feasible. ${ }^{12,13}$ With HTGR fuel, the $\mathrm{ThO}_{2}$ formed by oxidation of the $\mathrm{ThC}_{2}$ must be dissolved since a substantial por- tion of the uranium is trapped in the solid $\mathrm{ThO}_{2}$. Conventional Thorex reagent, $13 \mathrm{M} \mathrm{HNO}_{3}$ $0.04 \mathrm{M} \mathrm{HF}$, may be used to dissolve this material. Results of leaching tests carried out with oxidation product obtained in the burning of HTGR fuel in the fluidized bed of alumina ${ }^{14,15}$ showed that $>99 \%$ of the uranium may be recovered by these means.

\section{Clad $\mathrm{UO}_{2}$ Power Reactor Fuels}

Other fuel types studied were the stainless steel clad and Zircaloy clad $\mathrm{UO}_{2}$ power reactor fuels. With stainless steel clad fuels it does not appear practical to consider removal of the cladding by volatilization. However, the stainless steel cladding has been found to be subject to rapid attack and disintegration by means of a fluoride-catalyzed reaction with oxygen. Originally, metal fluorides ${ }^{16}$ such as $\mathrm{FeF}_{3}$ and $\mathrm{AlF}_{3}$ were used as the catalyst; however, gaseous $\mathrm{HF}$ was found to be more effective. ${ }^{17}$ The end products of the reaction of either $\mathrm{FeF}_{3}-\mathrm{O}_{2}$ or $\mathrm{HF}-\mathrm{O}_{2}$ with the stainless steel in an alumina fluidized bed were found to be oxides of the metals. In the $\mathrm{HF}$-catalyzed oxidation, the $\mathrm{UO}_{2}$ oxidizes to form $\mathrm{U}_{3} \mathrm{O}_{8}$ which then may be reacted with fluorine to form volatile uranium hexafluoride. The iron, nick$\mathrm{el}$, and chromium oxides teact will the fluorine to form products which, with the exception of some chromium fluorides and oxyfluorides, are nonvolatile. The major reactions occuriing ate sliuwı below:

$$
\begin{aligned}
& \mathrm{HF} \\
& 650^{\circ} \\
& (\mathrm{Fe}, \mathrm{Ni}, \mathrm{Cr})+\mathrm{O}_{2} \rightarrow(\mathrm{Fe}, \mathrm{Ni}, \mathrm{Cr}) \text { oxides } \\
& \mathrm{HF} \\
& 650^{\circ} \\
& 3 \mathrm{UU}_{2}(s)+\mathrm{U}_{2}(g) \rightarrow \mathrm{U}_{3} \mathrm{O}_{8}(s) \\
& \mathrm{U}_{3} \mathrm{O}_{8}(s)+9 \mathrm{~F}_{2}(g) \stackrel{450^{\circ}}{\rightarrow} \quad 3 \mathrm{UF}_{6}(g)+4 \mathrm{O}_{2}(g)
\end{aligned}
$$

Zircaloy clad $\mathrm{UO}_{2}$ fuels may be reacted in the same manner as the stainless steel clad fuels. ${ }^{14}$ $\mathrm{ZrO}_{2}$ is formed during the $\mathrm{HF}$-catalyzed oxidation. The major reactions occurring are as follows: 


$$
\begin{aligned}
\mathrm{HF} & \stackrel{\mathrm{HF}}{650^{\circ}} \\
\mathrm{Zr}(s)+\mathrm{O}_{2}(g) \stackrel{\mathrm{ZrO}_{2}(s)}{ } & \stackrel{\mathrm{HF}_{\circ}}{650^{\circ}} \\
3 \mathrm{UO}_{2}(s)+\mathrm{O}_{2}(g) & \stackrel{4}{\rightarrow} \mathrm{U}_{3} \mathrm{O}_{8}(s) \\
\mathrm{U}_{3} \mathrm{O}_{8}(s)+9 \mathrm{~F}_{2}(g) & \rightarrow 30^{\circ} \\
\rightarrow & 3 \mathrm{UF}_{6}(g)+4 \mathrm{O}_{2}(g)
\end{aligned}
$$

The effect of variation in feed gas composition on reaction rate (measured by weight loss of the metal coupons, and expressed as penetration) was determined for the HF-catalyzed oxidation of type 348 stainless steel (Fig. 4), and Zircaloy-2 (Fig. 5). The curves are similar for both cladding materials. Reaction rate rose rapidly as the HF fraction in the $\mathrm{HF}-\mathrm{O}_{2}$ feed gas was increased, and reached a maximum at $40 \% \mathrm{HF}$. With still higher HF fractions, the rate decreased. Experiments were carried out to determine the effect of temperature on reaction rate for both stainless steel and Zircaloy-2 using the optimum decladding mixtures of $40 \% \mathrm{HF}-60 \%$ oxygen, and the results are presented in Fig. 6. At temperatures below $500^{\circ} \mathrm{C}$ essentially no reaction took place. Above $500^{\circ} \mathrm{C}$ the penetration rate rose rapidly with increasing temperature. With stainless steel, a maximum rate of $-60 \mathrm{mils} / \mathrm{hr}$ was reached at a temperature of $650^{\circ} \mathrm{C}$ above which a gradual decrease in rate occurred. The curve for Zircaloy follows that of stainless steel very closely to a temperature level of $630^{\circ} \mathrm{C}$, above which it shows

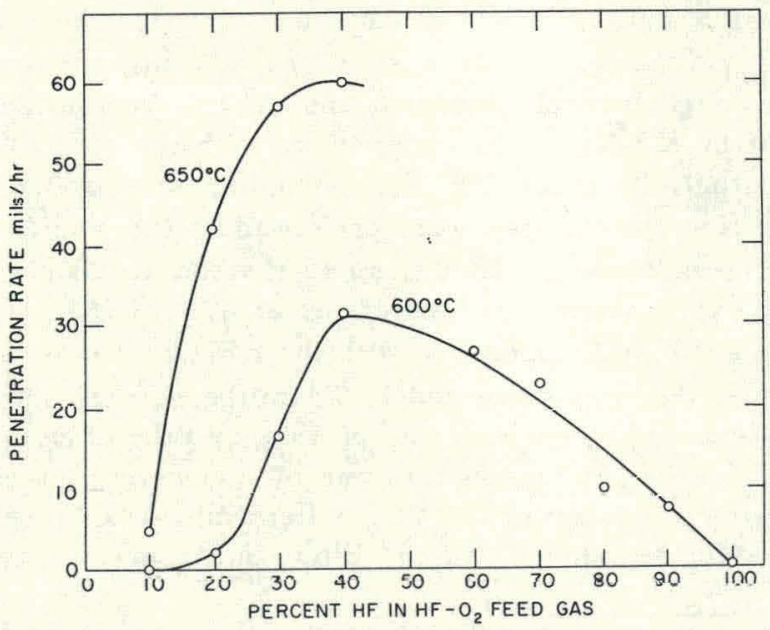

Figure 4. Penetration rate $v s$ feed gas composition. Type 348 stainless steel. Reaction in fluid bed of 60 to 100 mesh Alundum.

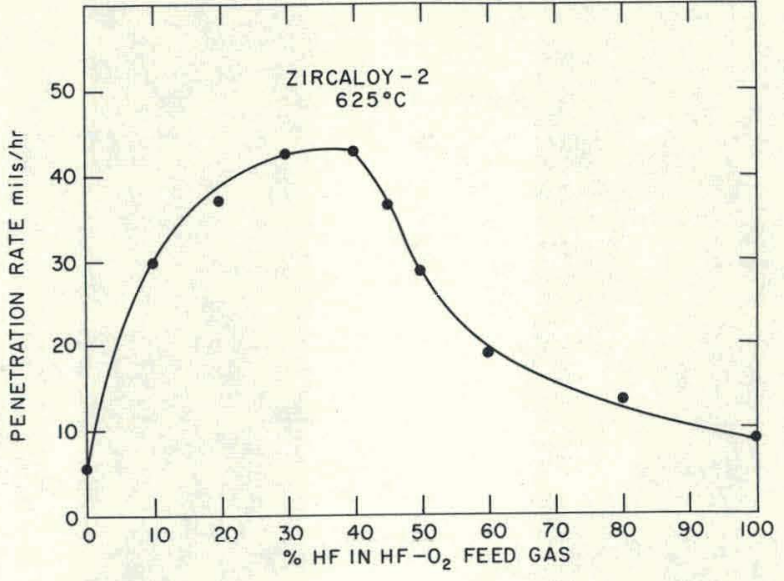

Figure 5. Penetration rate $v s$ feed gas composition. Reaction in fluid bed of 60 to 100 mesh Alundum.

that the reaction rate decreases rapidly. The inverse temperature effect displayed with both these cladding materials in the high temperature region may be considered to be of advantage in the reprocessing of large multirod fuel assemblies in that excessive temperature excursions, which lead to bed caking, may be prevented.

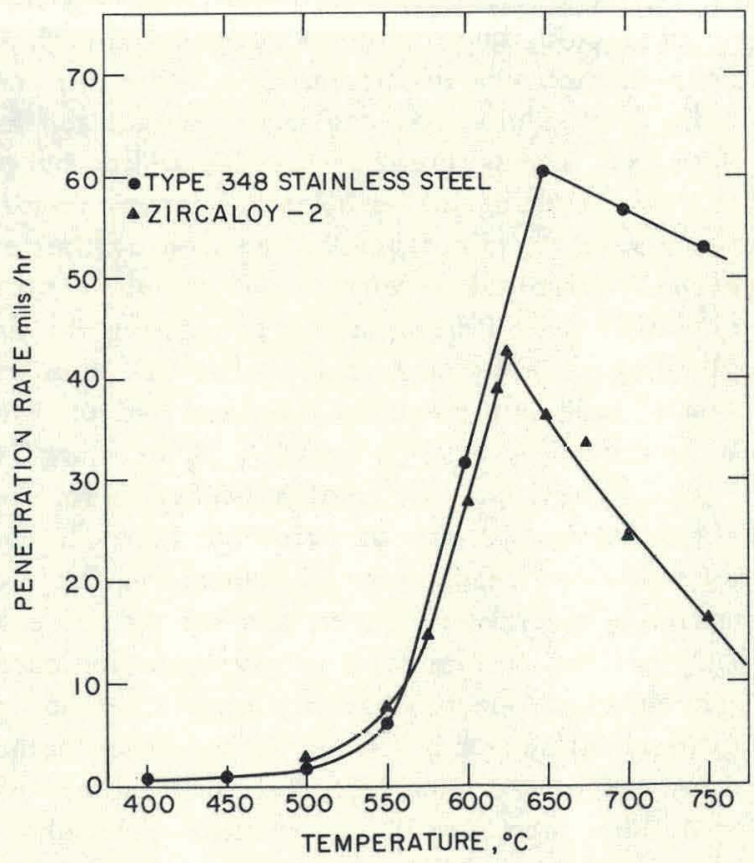

Figure 6. Penetration rate vs temperature. $40 \%$ $\mathrm{HF}-60 \% \mathrm{O}_{2}$. Reaction in fluid bed of 60 to 100 mesh Alundum. 

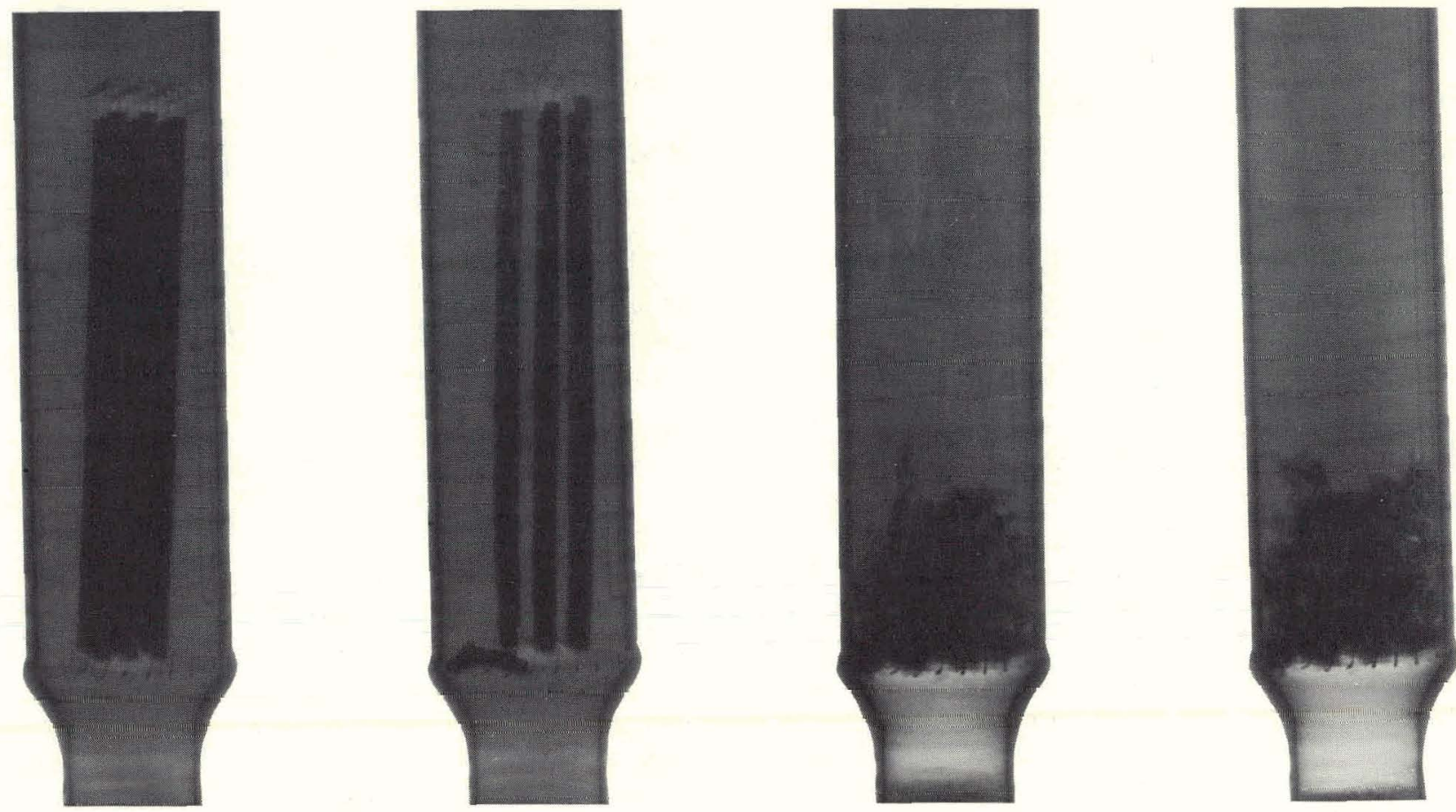

Figure 7. Decladding of 9-rod Zircaloy clad $\mathrm{UO}_{2}$ fuel assembly with $\mathrm{HF}-\mathrm{O}_{2}$ in a fluidized bed of alumina.

Decladding and uranium recovery studies have been carried out in laboratory scale equipment using both single rod and multiple fuel rod assemblies. The progress of the decladding operation with multirod assemblies has been observed using gamma radiography as reported by Bartlett et al. ${ }^{16}$ for 9-rod assemblics of stainless steel clad $\mathrm{UO}_{2}$ fuel. Radiographs made during the decladding of a 9-rod Zircaloy clad $\mathrm{UO}_{2}$ fuel assembly in a 3-in.-diameter fluidized bed of alumina at $625^{\circ} \mathrm{C}$ with $40 \% \mathrm{HF}-60 \% \mathrm{O}_{2}$ ate shown in Fig. 7. The first view shows the tuel before reaction. After $30 \mathrm{~min}$ of oxidation (View 2) the assembly had begun to swell because of the formation of a thick $\mathrm{ZrO}_{2}$ layer, and the presence of $\mathrm{UO}_{2}$ pellets on the fuel support grid indicates that at least one rod had ruptured. After an additional 30 min of reaction (View 3) the decladding was almost complete. The last radingraph, made after a total of 90 min reaction time, shows that the assembly had been completely disintegrated.

After completion of the studies on graphite matrix fuels, the BNL pilot plant was modified in order to carry out larger scale experiments with stainless steel clad and Zircaloy clad $\mathrm{UO}_{2}$ fuels. ${ }^{18,19} \mathrm{Fig} .8$ shows a view of one of the assemblies, a 16-rod cluster made up with 15-in.long "Yankep"-type fuel tods arranged in a $4 \times 4$ array. The assembly contained $2.5 \mathrm{~kg} \mathrm{UO}$ and $0.8 \mathrm{~kg}$ stainless steel. Fig. 9 shows a flow diagram for the process, and Table 1 summarizes the results of the experiments with the clad $\mathrm{UO}_{2}$ fuel. Both the $\mathrm{HF}-\mathrm{O}_{2}$ decladding step and the fluorination step were performed in the modified 4-in.-diameter fluidized-bed reactor. Decladding experiments were carried out at $600^{\circ}$ to $650^{\circ} \mathrm{C}$ as a two stage operation with the $\mathrm{HF} / \mathrm{O}_{2}$ ratio $40 / 60$ in the first stage and $25 / 75$ in the second. This provided for a high rate of attack on the cladding (in the first stage) followed by a moderate attack with breakup of the $\mathrm{UO}_{2}$ pellets into $\mathrm{U}_{3} \mathrm{O}_{6}$ fines* (in the second stage). Fluidization quality and

\footnotetext{
${ }^{*} \mathrm{U}_{3} \mathrm{O}_{8}$ fines are fluorinated readily and with little chance of bed caking whereas larger pieces of the $\mathrm{UO}_{2} \mathrm{~F}_{2}-\mathrm{UF}_{4}$ reaction product, which form when decladding is carried out with the $40 \% \mathrm{HF}-60 \% \mathrm{O}_{2}$ mixture, do not.
} 


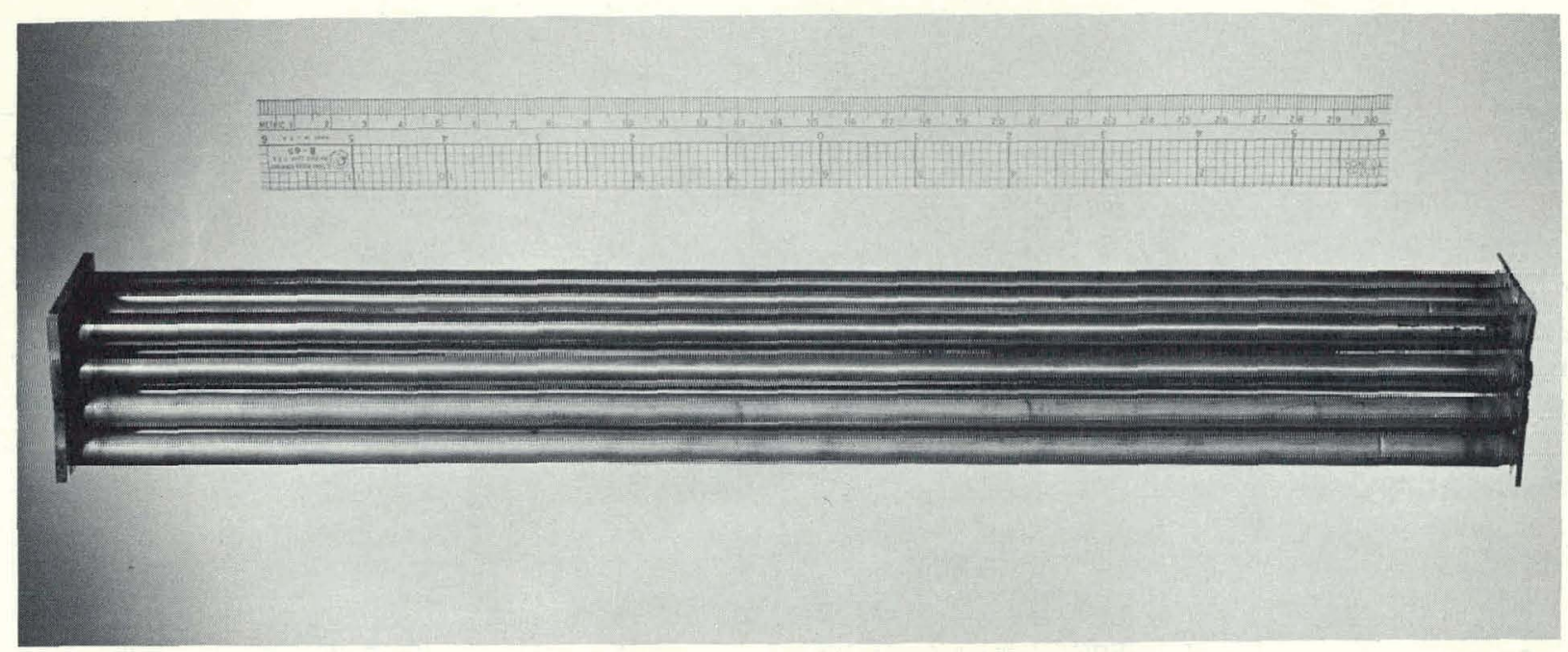

Figure 8. 16-rod "Yankee"-type fuel assembly used in pilot plant decladding fluorination studies.

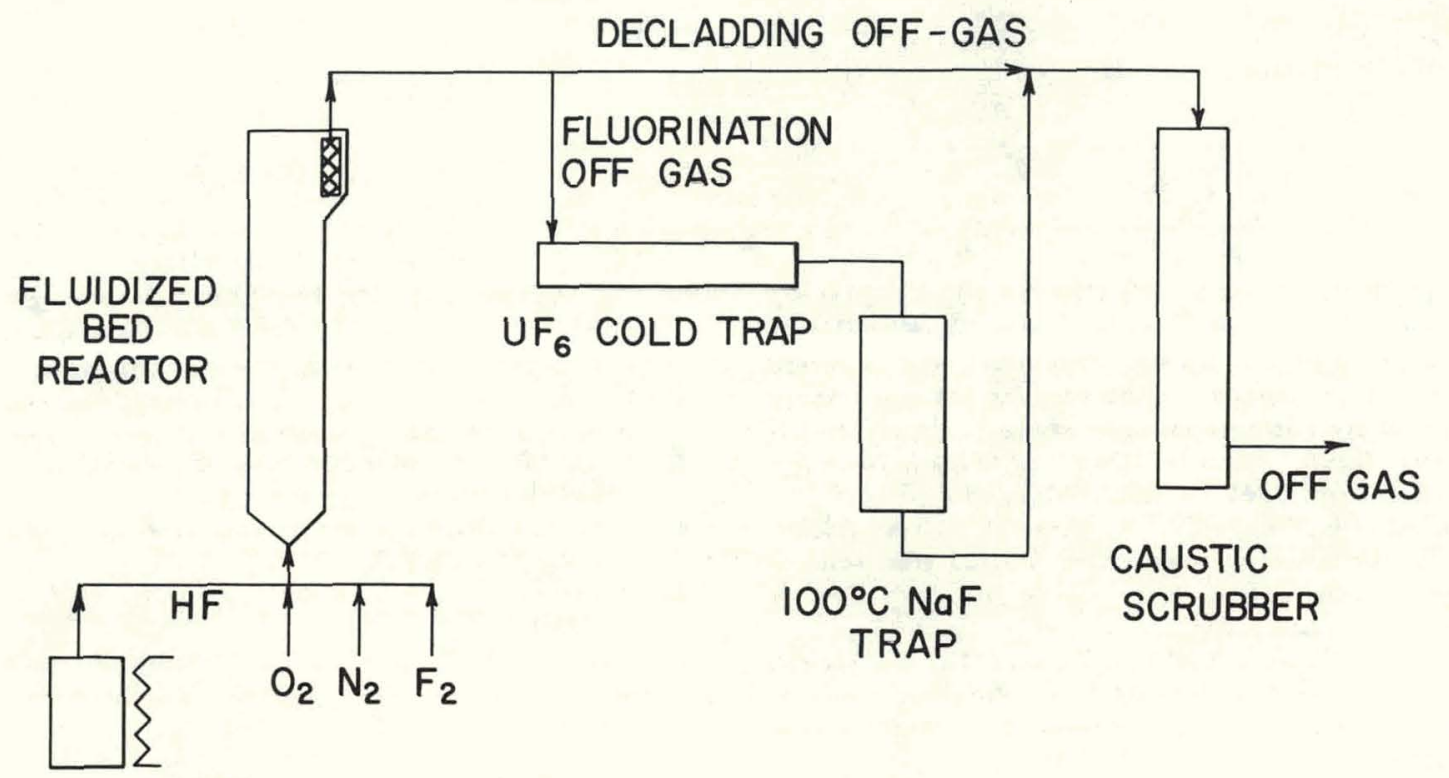

\section{HF BOILER}

Figure 9. Simplified pilot plant flow diagram for decladding-fluorination of clad power reactor fuels.

temperature control were good during the decladding of both stainless steel clad and Zircaloy clad $\mathrm{UO}_{2}$ fuel assemblies. The oxidation products were readily reacted at temperatures of $450^{\circ}$ to $500^{\circ} \mathrm{C}$ with fluorine-nitrogen mixtures containing 10 to $50 \% \mathrm{~F}_{2}$, and approximately $99 \%$ of the uranium was volatilized from the bed.

Presently, a 6-in.-diameter reactor vessel is being installed in the pilot plant to be used in decladding experiments with stainless steel clad and Zircaloy clad $\mathrm{UO}_{2}$ fuel assemblies made up with as many as 49 rods ( $7 \times 7$ array), 30 in. long. These BNL pilot plant decladding and fluorination studies are being carried out with unirradiated fuel to obtain basic engineering information to be used in support of the ORNL hot pilot plant program. ${ }^{20}$ 
Table 1

PILOT PLANT RUN SUMMARY

\begin{tabular}{|c|c|c|c|c|c|}
\hline \multirow[b]{2}{*}{ Run } & \multicolumn{4}{|c|}{ Yankee Fuel } & \multirow{2}{*}{$\frac{\text { Zircaloy-2 Fuel }}{Z r-1}$} \\
\hline & $S S-1$ & $S S-2$ & SS-3 & SS-4 & \\
\hline Fuel & 9-rod 15-in. long & 9-rod 30-in. long & 16-rod 15 -in. long & 25-rod 15-in. long & 9-rod 30-in. long \\
\hline Contained $\mathrm{UO}_{2}$ & $1.410 \mathrm{~kg}$ & $2.930 \mathrm{~kg}$ & $2.509 \mathrm{~kg}$ & $3.9 \mathrm{~kg}$ & $3.357 \mathrm{~kg}$ \\
\hline \multicolumn{6}{|l|}{ Total stainless steel } \\
\hline or Zircaloy-2 & $0.440 \mathrm{~kg}$ & $0.838 \mathrm{~kg}$ & $0.792 \mathrm{~kg}$ & $1.2 \mathrm{~kg}$ & $0.916 \mathrm{~kg}$ \\
\hline Total wt of fuel & $1.850 \mathrm{~kg}$ & $3.768 \mathrm{~kg}$ & $3.301 \mathrm{~kg}$ & $5.1 \mathrm{~kg}$ & $4.273 \mathrm{~kg}$ \\
\hline Alumina charge & $18.2 \mathrm{~kg}$ & $23.6 \mathrm{~kg}$ & $18.2 \mathrm{~kg}$ & $18.2 \mathrm{~kg}$ & $23.6 \mathrm{~kg}$ \\
\hline $\mathrm{U} / \mathrm{Al}_{2} \mathrm{O}_{3}$ ratio & 0.068 & 0.110 & 0.121 & 0.189 & 0.125 \\
\hline $\mathrm{SS}$ Fluoride $/ \mathrm{Al}_{2} \mathrm{O}_{3}$ ratio & 0.044 & 0.064 & 0.079 & & 0.062 \\
\hline \multicolumn{6}{|l|}{ HF -oxidation } \\
\hline $40 \% \mathrm{HF}-60 \% \mathrm{O}_{2}$ & $39 \mathrm{~min}$ & $1 \mathrm{hr}$ & $1 \mathrm{hr} 15 \mathrm{~min}$ & $35 \mathrm{~min}$ & $30 \mathrm{~min}$ \\
\hline $25 \% \mathrm{HF}-75 \% \mathrm{O}_{2}$ & $1 \mathrm{hr} 51 \mathrm{~min}$ & $3 \mathrm{hr} 20 \mathrm{~min}$ & $3 \mathrm{hr} 28 \mathrm{~min}$ & $1 \mathrm{hr}$ & $2 \mathrm{hr} 30 \mathrm{~min}$ \\
\hline Total & $2 \mathrm{hr} 30 \mathrm{~min}$ & $4 \mathrm{hr} 20 \mathrm{~min}$ & $4 \mathrm{hr} 43 \mathrm{~min}$ & $1 \mathrm{hr} 35 \mathrm{~min}$ & $3 \mathrm{hr}$ \\
\hline \multicolumn{6}{|l|}{ Fluorination } \\
\hline $25 \% \mathrm{~F}_{2}-75 \% \mathrm{~N}_{2}$ & & $2 \ln 20 \mathrm{~min}$ & $2 \mathrm{hr} 20 \mathrm{~min}$ & & $2 \mathrm{hr} 28 \mathrm{~min}$ \\
\hline $50 \% \mathrm{~F}_{2}-50 \% \mathrm{~N}_{2}$ & & $1 \mathrm{hr} 5 \mathrm{~min}$ & $1 \mathrm{hr} 0 \mathrm{~min}$ & & $30 \mathrm{~min}$ \\
\hline Total time & $2 \mathrm{hr} 20 \mathrm{~min}$ & $3 \mathrm{hr} 25 \mathrm{~min}$ & $3 \mathrm{hr} 20 \mathrm{~min}$ & & $2 \mathrm{hr} 58 \mathrm{~min}$ \\
\hline Total $\mathrm{F}_{2}$ charge & $6 \mathrm{lb}$ & $10 \mathrm{lb}$ & $10 \mathrm{lb}$ & & $7.5 \mathrm{lb}$ \\
\hline $\mathrm{U}$ in bed after fluorination & $0.025 \%$ & $0.107 \%$ & $0.16 \%$ & & $0.17 \%$ \\
\hline
\end{tabular}

\section{REFERENCES}

1. Vogel, R.C., Carr, W. H., Cathers, G. I., Fisher, J., Hatch, L. P., Horton, R. W., Jonke, A. A., Milford, R. P., Reilly, J. J., and Strickland, G., Fluoride volatility processes for the recovery of fissionable material from irradiated reactor fuels. Proc. $3 r d \cup N$ Intern. Conf. Peaceful Uses of Atomic Energy, Geneva, Sept. 1964 (A/Conf. 28/P/250).

2. Reilly, J. J., Regan, W. H., Wirsing, E., and Hatch, L. P., Uranium recovery from unirradiated reactor fuel elements. Ind. Eng. Chem. Process Design Develop. 2, 127 (1963).

3. Regan, W. H., Reilly, J. J., Wirsing, E., and Hatch, L. P., The Application of Inert Fluidized Beds to the Volatilization Reprocessing of Reactor Fuels Informal Report. BNL 6195, 1962.

4. Ramaswami, D., Levitz, N. M., and Jonke, A. A., Engineering development of a tluid-bed tluoride volatility process I. Nucl. Appl. 1, 293-300, Aug. 1965.

5. Holmes, J. T., Stethers, H., and Borghusen, J. J., Engineering development of a fluid-bed fluoride volatility process II. Nucl. Appl. 1, 301-9, Aug. $1,9 \sqrt{1}, 5$.

6. Culler, F. L., Jr., Rover Report for June 1962, ORNL-TM-298 (classified).

7. Haas, P. A., and Ferris, L. M., Dissolution of graphite-base reactor fuels by pressurized aqueous processes R10. Presented at Am. Chem. Soc. Meeting, Sept. 1965.

8. Culler, F. L., Jr., Rover Repart for April 1964. ORNL-TM-884 (classified).

9. Reilly, J. J., Wachtel, S. J., Johnson, R., Wirsing,
E., and Hatch, L. P., Fluidized bed reprocessing of graphite matrix nuclear fuel. Ind. Eng. Chem. Process Design Develop. 5, 51-9 (1966).

10. Hatch, L. P., Reilly, J. J., Wirsing, E., and Johnson, R., Progress Report on Reprocessing Rover Fuel. BNL Memorandum to W. E. Winsche, July 25, 1962 (classified).

11. Spence, R. W., Nuclear rockets。 Intern. Sci. Technol., No. $43,58-65$, July 1965 .

12. Bimonthly Progress Report, Volatility Process Development. Nov.-Dec. 1463 (classified).

13. Reilly, J. J., Wachtel, S. J., Johnson, R., Wirsing, E., and Hatch, L. P., Fluidized Bed Reprocessing of Rover Fuel, BNL 885 (classified).

14. Annual Report, Nuclear Engineering Department. BNL 900 (S-67), pp. 45-51, Dec. 31, 1964.

15. Brookhaven National Laboratory Bimonthly Report, Volatility Process Development. Nov.-Dec. 1964.

16. Bartlett, C. B., Wirsing, E., Wachtel, S. J., Johnson, R., Reilly, J. J., and Hatch, L. P., Fluidized Bed Reprocessing of Stainless Steel-Clad $\mathrm{UO}_{2}$ Power Reactor Fuels. BNL 968 (T-406), 1966.

17. Oak Ridge National Laboratory Status and Progress Report. ORNL 3614, pp. 12-13, March 1964.

18. Brookbaven National Laboratory Bimonthly Report, Volatility Process Development. May-June 1965.

19. Brookbaven National Laboratory Bimonthly Report, Volatility Process Development. July-August 1965.

20. Milford, R. P., Proposed Design of a Fluidized-Bed Fluoride-Volatility Pilot Plant for Installation at Oak Ridge National Laboratory. ORNL-TM-972, Oct. 26, 1964. 


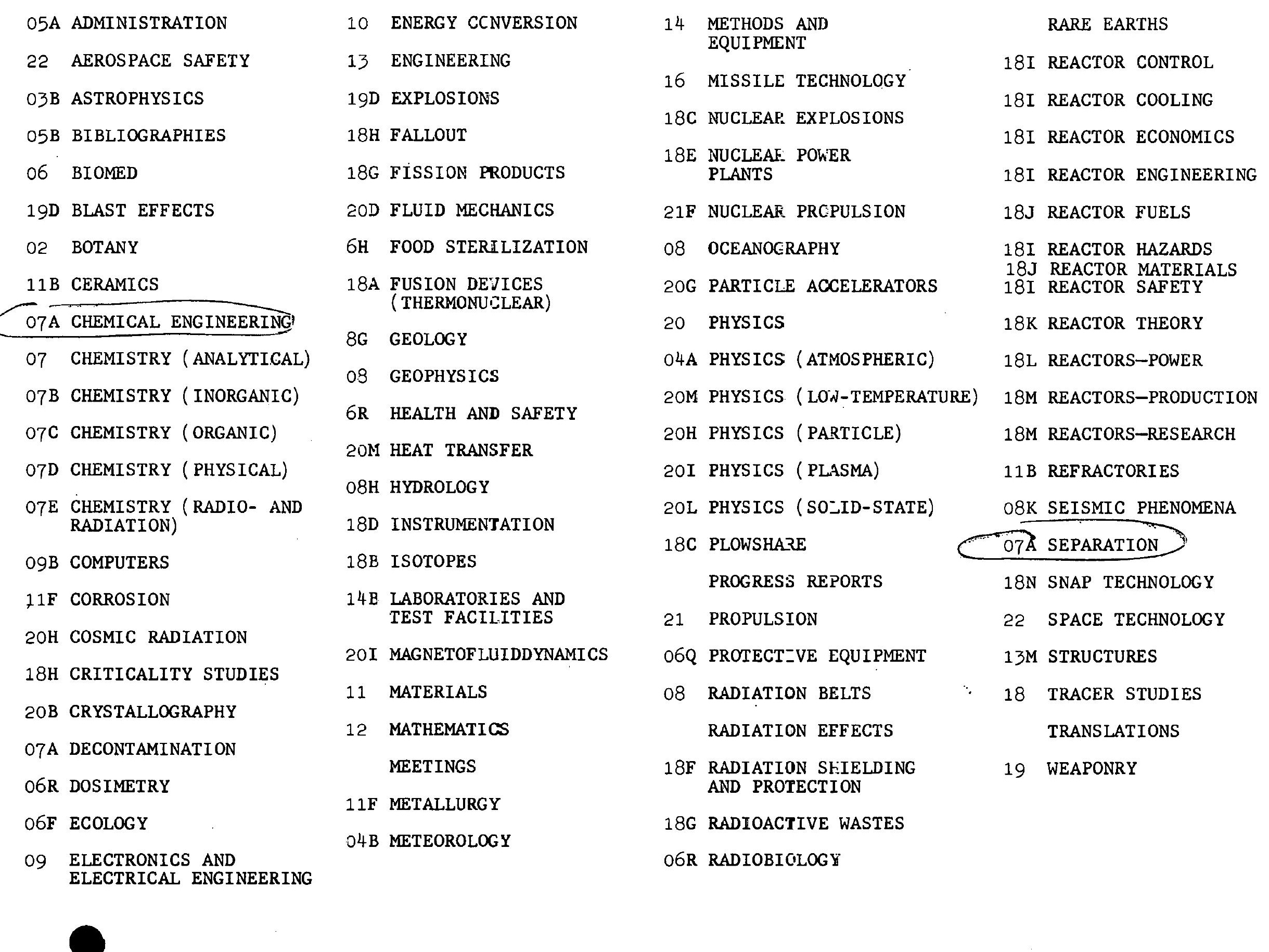

